\title{
Pengaruh Exchange Rate, Inflasi, Risiko Sistematis Dan BI Rate Terhadap Return Saham Syariah Di Jakarta Islamic Index (JII) Periode 2015-2018
}

\author{
Ahmad Karim Abdul Jabar 1, Iwan Fahri Cahyadi2 \\ 1,2Institut Agama Islam Negeri Kudus, Kudus \\ $\bigotimes^{1}$ kariembinjabbar007@gmail.ac.id, $\rrbracket^{2}$ iwanfahri@iainkudus.ac.id
}

\begin{abstract}
This research aims to determine the effect of variable exchange rate, inflation, systematic risk, and bi rate partially on the return of sharia stocks in the Jakarta Islamic Index (JII). In addition, to know the effect of variable exchange rate, inflation, systematic risk, and BI rate simultaneously on the return of sharia stocks in Jakarta Islamic Index (JII) period 2015-2018. This type of research is quantitative research with secondary data sources. The sampling method uses the purposive sampling method. This research data uses sharia stock data listed in Jakarta Islamic Index period 2015-2018. The method of data analysis used is to use multiple linear regression analysis methods. The results of this study show that partially variable exchange rate (X1) negatively and significantly affects the return of sharia stocks with a value of $t$ count $>$ t-table $(2.482>1,998)$ and a significant rate of $0.016>0.05$, while inflation also negatively and significantly affects the return of sharia stocks with a value of t-count $>t$-table $(2,600>1,998)$ and $a$ significant level of $0.012<0.05$, and systematic risk (X3) affects the return of sharia stocks with a value of $t$-count $>t$-table $(2.038>1.998)$ and a significant level of $0.046<0.05$, while the BI rate $(X 4)$ negatively and significantly affects the return of sharia stocks, with a value of $t$ count $>$ t-table $(2.412>1,998)$ and a significant level of $0.019<0.05$. Simultaneously indicates that the exchange rate, inflation, systematic risk, and BI rate significantly affect the return of sharia stocks with a value of F-count $>$ F-table $(2.810>2.52)$ with a significance value of 0.033 .
\end{abstract}

Keywords : exchange rate, inflation, systematic risk, BI rate and return of sharia stocks.

\section{LATAR BELAKANG}

Dalam perspektif perekonomian secara agregat, peran pasar modal dalam memajukan perekonomian suatu negara sangat penting, karena peran pasar modal dapat menunjang perekonomian negara dalam banyak sektor. Pasar modal adalah tempat bertemunya dua pihak yang memiliki dana lebih (lender) dan pihak yang membutuhkan dana (borrower) dalam waktu jangka panjang dengan cara memperjual belikan sekuritas. Tempat terjadinya proses jual beli sekuritas disebut bursa efek (Hadi, 2015a). 
Perekonomian yang tumbuh dan stabil dapat memberikan angin segar bagi perusahaan karena akan meningkatkan laba perusahaan. Peningkatan laba oleh perusahaan dapat ditempuh dengan berbagai cara. Salah satunya dengan berinvestasi pada pasar modal. Kegiatan investasi merupakan kegiatan yang menempatkan suatu dana pada satu atau lebih aset selama periode tertentu dengan harapan memperoleh pandapatan atau peningkatan atas nilai investasi awal yang bertujuan untuk memaksimalkan hasil (return) yang diharapkan dalam batas risiko yang dapat diterima untuk tiap investor (Tandelilin, 2001a).

Namun banyak hal yang harus dipertimbangkan dalam melakukan investasi. Tujuan utama dari aktivitas di pasar modal adalah untuk mendapatkan keuntungan (return). Para investor menggunakan berbagai cara untuk mendapatkan return yang diharapkan, baik dengan melakukan analisis sendiri terhadap perilaku perdagangan saham, maupun dengan memanfaatkan saran yang diberikan oleh para analis pasar modal seperti dealer, broker, manajer investasi dan lain-lain.

Pasar modal merupakan salah satu alternatif sumber pendanaan bagi perusahaan sekaligus sebagai sarana investasi bagi para pemodal. Kegiatankegiatan di pasar modal dapat dikategorikan sebagai kegiatan ekonomi yang termasuk dalam kegiatan muamalah, yaitu suatu kegiatan yang mengatur hubungan perniagaan. Menurut kaidah fiqh, hukum asal dari kegiatan muamalah adalah mubah (boleh), kecuali ada dalil yang jelas melarangnya. Beberapa larangan dalam kegiatan pembiayaan dan investasi oleh syariah antara lain adalah transaksi yang mengandung riba', mengandung gharar (ketidakjelasan), maysir, maksiat dan kedzaliman. Para ulama sepakat bahwa perdagangan saham dibolehkan secara syariah. Ibnu Qudamah dalam Al-Mughni menyebutkan bahwa jika salah seorang dari dua orang berserikat membeli porsi mitra serikatnya, hukumnya boleh karena ia membeli milik pihak lain (Umam, 2013a).

Secara umum investor tidak dapat mengetahui secara pasti besarnya total return yang akan diperoleh. Oleh karena itu, diperoleh analisis untuk memprediksi return saham sebelum berinvestasi pada suatu perusahaan. Beberapa faktor yang diduga mempengaruhi return saham adalah exchange rate, inflasi, risiko dan BI rate. Penelitian ini dilakukan untuk membuktikan pengaruh faktor-faktor tersebut terhadap return saham syariah.

Salah satu Indeks Saham yang ada di Bursa Efek Indonesia (BEI) adalah Jakarta Islamic Index. Selama ini, investasi syariah di pasar modal Indonesia identik dengan Jakarta Islamic Index (JII) yang hanya terdiri dari 30 sahamSyariah yang tercatat di Bursa Efek Indonesia (BEI). Saham syariah yang menjadi konstituen JII terdiri dari 30 saham yang merupakan saham-saham syariah paling likuid dan memiliki kapitalisasi pasar yang besar. BEI melakukan review JII setiap 6 bulan, yang disesuaikan dengan periode penerbitan DES oleh Bapepam \& LK. Setelah dilakukan penyeleksian saham syariah oleh Bapepam \& LK yang dituangkan ke dalam DES, BEI melakukan proses seleksi lanjutan yang didasarkan kepada kinerja perdagangannya.

Perkembangan saham Syariah menunjukkan hal positif, terlihat dari jumlah saham yang semakin banyak. Di tahun 2015 dalam Daftar Efek Syariah (DES) terdapat 331 saham dan meningkat pada tahun 2018 sebanyak 414 saham. 
Pola harga saham yang fluktuatif akan mempengaruhi return saham yang akan diperoleh oleh pemegang saham atau investor. Harga saham yang fluktuatif dipengaruhi oleh beberapa hal. Pertama oleh kondisi eksternal perusahaan, kedua oleh kondisi internal perusahaan (faktor fundamental) tersebut. Kondisi eksternal antara lain yaitu faktor variabel makroekonomi suatu negara. Variabel makroekonomi tersebut diantaranya adalah exchange rate (nilai tukar), inflasi, risiko sistematis, dan tingkat suku bunga BI Rate.

Faktor fundamental adalah faktor yang berasal dari dalam perusahahaan yang mengeluarkan saham itu sendiri (emiten). Apabila perusahaan yang mengeluarkan saham dalam kondisi yang baik kinerjanya, maka harga saham akan cenderung meningkat dan apabila harga saham meningkat maka return yang diterima juga meningkat. Hal ini disebabkan kepercayaan investor terhadap emiten semakin baik, investor mempunyai harapan akan memperoleh keuntungan atau deviden yang besar. Faktor fundamental ini bisa dilihat dari laporan keuangan, dan dari laporan keuangan emiten bisa dilihat tingkat kinerja keuangannya baik dari segi kemampuan untuk menghasilkan keuntungan (profitabilitas), kemampuan membayar hutang (solvabilitas), maupun tingkat efisiensi dan efektivitasnya dalam mengelola kekayaan (Sudarsono dan Sudiyatno, 2016a).

Banyak hal yang mempengaruhi kinerja perusahaan, salah satunya adalah nilai tukar rupiah yang berubah, perubahan ini mencerminkan perusahaan tersebut mengalami foreign exchange exposure (eksposur nilai tukar). Perubahan nilai tukar yang tidak bisa diramalkan inilah yang menjadi latar belakang penelitian ini dilakukan. Penelitian ini melihat bagaimana dampak perubahan nilai tukar mampu mempengaruhi penerimaan dan penawaran yang pada akhirnya akan merubah tingkat profitabilitas perusahaan dan memberikan pengaruh besar pada return saham. Return saham akan mencerminkan bagaimana kinerja sebuah perusahaan sehingga investor yang akan berinvestasi bisa menjadikan return saham sebagai salah satu pertimbangan investasi yang akan investor lakukan. Dalam penelitian ini ingin melihat bagaimana perubahan return saham yang akan terjadi apabila rupiah dipandang lemah oleh dolar atau apabila rupiah dipandang kuat oleh dolar (Pujawati, 2015a).

Tingginya tingkat inflasi menunjukkan bahwa risiko untuk melakukan investasi cukup besar sebab inflasi yang tinggi akan mengurangi tingkat pengembalian dari investor. Pada kondisi inflasi yang tinggi maka harga barang atau bahan baku memiliki kecenderungan untuk meningkat. Peningkatan harga barang-barang dan bahan baku akan membuat biaya produksi menjadi meningkat sehingga akan berpengaruh pada penurunan jumlah permintaan yang berakibat pada penurunan penjualan sehingga mengurangi pendapatan perusahaan. Selanjutnya akan berdampak pada kinerja perusahaan dan akan menurunkan return saham perusahaan.

Berdasarkan laporan Bank Indonesia bahwa inflasi pada tahun 2013 terjadi kenaikan dari periode sebelumnya sebesar 2,69\%, hal ini menjadikan salah satu indikasi bahwa krisis keuangan yang terjadi di AS pada tahun 2008 mulai berdampak pada Indonesia. Walaupun inflasi sempat turun pada tahun 2012, namun naik kembali di tahun 2013 akibat dampak krisis di Eropa. Kenaikan 
inflasi dapat mempengaruhi investor dalam melakukan investasi, apalagi investasi saham yang tingkat risikonya tinggi. Dan pada tahun 2014, 2015 dan 2016 laju inflasi mengalami penurunan sebesar 0,56\%, 0,03\% dan 2,85\%, dan mengalami kenaikan kembali pada tahun 2017 yaitu sebesar 0,27\%, kemudian turun sebesar 0,6\% pada tahun 2018 .

Faktor lain yang mempengaruhi return saham adalah Risiko investasi. Risiko investasi yang sesungguhnya adalah ketidaksesuaian antara expected return dengan return aktualnya (actual return). Artinya, risiko merupakan penyimpangan dari fakta return yang diterima (actual return). Untuk itu, menghitung risiko investasi dapat ditentukan dari tingkat penyimpangan return yang diharapkan (Hadi, 2015b).

Jadi dengan menghitung sebuah risiko investasi maka investor dapat mengetahui risiko yang akan diterima dalam berinvestasi dan juga investor dapat memperkirakan apakah akan tetap berinvestasi atau tidak, dan hal ini juga dapat mempengaruhi jumlah return saham yang akan diterima nantinya.

Faktor selanjutnya yang dapat memepengaruhi return saham yaitu BI Rate. BI Rate merupakan faktor yang dapat mempengaruhi perubahan harga saham dan akan mempengaruhi return saham juga. BI rate merupakan suku bunga kebijakan moneter yang ditetapkan oleh BankIndonesia. Apabila tingkat suku bunga naik, maka akan terjadi peningkatan suku bunga kredit. Jika suku bunga kredit naik, maka biaya modal yang dikeluarkan emiten akan semakin besar sehingga minat emiten untuk meminjam dana pada bank akan menurun karena beban bunga tersebut. Hal tersebut membuat dana pinjaman yang diperoleh emiten semakin kecil sehingga dapat menurunkan tingkat penjualan. Jika tingkat penjualan menurun, maka laba dalam perusahaan juga mengalami penurunan. Apabila laba turun maka harga saham juga akan mengalami penurunan diikuti oleh penurunan return yang diperoleh pemegang saham. Sebaliknya apabila suku bunga turun maka akan diikuti penurunan suku bunga kredit sehingga bunga pinjaman yang dilakukan emiten bisa semakin besar. Keadaan tersebut mendorong emiten untuk lebih meningkatkan penjualan produknya. Semakin tinggi tingkat penjualan maka laba perusahaan akan semakin besar. Perusahaan yang memiliki laba besar membuat harga saham akan mengalami peningkataan diikuti oleh peningkatan return yang diperoleh pemegang saham (Afiyati dan Topowijoyo, 2018a).

Banyak penelitian yang meneliti pengaruh makroekonomi terhadap return saham. Penelitian yang dilakukan oleh Eka, Bagus dan Sri Artini tahun 2015 menemukan bahwa nilai tukar berpengaruh negatif dan signifikan terhadap return saham. Hasil penelitian ini sejalan dengan penelitian yang dilakukan oleh Kadek dan Mertha tahun 2018 bahwa nilai tukar berpengaruh negatif dan signifikan terhadap return saham. Berbeda dengan penelitian yang dilakukan oleh Hidaya Tri Afiyati dan Topowijono tahun 2018 bahwa nilai tukar berpengaruh signifikan terhadap return saham.

Penelitian yang dilakukan Dani Ahmad Luthvi tahun 2014 yang menemukan bahwa variable tingkat inflasi berpengaruh negatif terhadap return saham syariah di Indonesia. Hasil penelitian ini berbeda penelitian yang dilakukan Hidaya Tri Afiyati dan Topowijono tahun 2018 bahwa inflasi tidak berpengaruh 
signifikan terhadap return saham. Dan Ni Kadek Suryani dan Gede Mertha Sudiartha tahun 2018 yang menemukan bahwa variable tingkat inflasi berpengaruh negatif dan tidak signifikan terhadap return saham.

Sedangkan dalam penelitian lain mengenai variabel risiko yang dilakukan Yodi Rizmanto tahun 2015 menemukan bahawa variabel risiko sistematis berpengaruh positif dan signifikan terhadap return saham. Hasil penelitian ini berbeda dengan penelitian yang dilakukan Inggit Nugroho dan Sukhemi tahun 2015 bahwa risiko sistematis berpengaruh negatif dan signifikan terhadap return saham.

Dalam penelitian lain mengenai variabel makroekonomi selanjutnya yaitu tentang BI Rate. Penelitian yang dilakukan Hidaya Tri Afiyati dan Topowijono tahun 2018 yang menemukan bahwa BI Rate tidak berpengaruh signifikan terhadap return saham. Hasil penelitian ini sejalan dengan penelitian yang dilakukan oleh Dede Abdul Rozak tahun 2013 bahwa BI Rate tidak berpengaruh secara signifikan terhadap return saham.

Beberapa penelitian yang berhubungan antara exchange rate, inflasi, risiko sistematis dan BI rate terhadap return saham menunjukkan bahwa ada inkonsisten hasil yang didapat dari beberapa penelitian tersebut. Sehingga mendorong peneliti untuk melakukan penelitian kembali faktor-faktor eksternal perusahaan yang mempengaruhi return saham syariah di JII dengan judul "Pengaruh Exchange Rate, Inflasi, Risiko Sistematis, dan BI Rate Terhadap Return Saham Syariah di Jakarta Islamic Index (JII) Periode 2015-2018”

\section{TEORI DAN METODE}

\subsubsection{Pasar Modal}

Pasar modal merupakan indikator perekonomian suatu negara. Pada dasarnya, pasar modal merupakan pasar atau sarana bagi investor dalam berbagai transaksi instrumen keuangan atau surat-surat berharga yang bisa diperjual belikan dalam bentuk utang atau modal. Pasar modal memberikan fasilitas untuk mempertemukan antara pihal-pihak surplus dana (surplus fund) dengan pihak yang membutuhkan dana (defisit fund) dalam kerangka investasi (Hadi, 2015c).

Perusahaan yang membutuhkan dana dapat menjual surat berharganya ke pasar modal. Surat berharga yang baru dikeluarkan oleh perusahaan pada saat Initial Public Offering (IPO) dijual di pasar primer. Surat berharga yang sudah beredar, kemudian diperdagangkan di pasar sekunder. Pasar ketiga dijalankan oleh broker pada saat pasar sekunder (kedua) tutup. Pasar keempat dilakukan diantara institusi berkapasitas besar untuk menghindari komisi broker dan biasanya menggunakan jaringan komunikasi untuk memperdagangkan saham dalam jumlah blok yang besar, misalnya Instinet yang dimiliki oleh Reuter yang menangani lebih dari satu miliar lembar saham tiap tahunnya (Hartono, 2017a). Oleh karena itu pembahasan pasar modal dimulai dari definisinya, instrumennya, dan analisis ekonomi. Oleh karena itu pembahasan pasar modal dimulai dari definisinya, instrumennya, dan analisis ekonomi. 


\section{a. Definisi Pasar Modal}

Pasar modal adalah pertemuan antara pihak yang memiliki kelebihan dana dengan pihak yang membutuhkan dana dengan cara memperjualbelikan sekuritas. Pasar modal juga diartikan sebagai pasar untuk memperjualbelikan sekuritas yang umumnya memiliki umur lebih dari satu tahun, seperti saham dan obligasi. Sedangkan tempat dimana terjadinya jual beli sekuritas disebut dengan bursa efek. Maka dari itu, bursa efek merupakan arti dari pasar modal secara fisik (Tandelilin, 2001b).

Pasar modal berfungsi sebagai lembaga perantara yang memiliki peran penting dalam menunjang perekonomian untuk menghubungkan pihak yang membutuhkan dana dengan pihak yang kelebihan dana. Selain itu, pasar modal dapat mendorong terciptanya alokasi dana yang efisien, karena dengan adanya pasar modal maka pihak yang kelebihan dana dapat memilih alternatif investasi yang memberikan return yang paling optimal. Asumsinya, investasi yang memberikan return relatif besar adalah sektorsektor yang paling produktif yang ada di pasar. Dalam Islam, investasi merupakan kegiatan muamalah yang sangat dianjurkan, karena dengan berinvestasi harta yang dimiliki menjadi produktif dan juga mendatangkan manfaat bagi orang lain.

Dalam sebuah hadits, Nabi Muhammad Saw bersabda, "Ketahuilah, Siapa yang memelihara anak yatim, sedangkan anak yatim itu memiliki harta, maka hendaklah ia menginvestasikannya (membisniskannya), janganlah ia membiarkan harta itu idle, sehingga harta itu terus berkurang lantaran zakat".

Kegiatan pasar modal di Indonesia diatur dalam Undang-Undang Republik Indonesia No. 8 tahun 1995 tentang pasar modal (UUPM). UUPM tidak membedakan apakah kegiatan pasar modal dilakukan dengan prinsip syariah atau tidak. Dilihat dari legal formalnya, pasar modal dengan prinsip-prinsip syariah berdiri pada tanggal 14 Maret 2003. Perkembangan pasar modal syariah saat ini ditandai dengan maraknya perusahaan yang listing di Jakarta Islamic Index, penawaran umum Obligasi Syariah, dan Reksadana Syariah (Darmadji dan Fakhruddin, 2011a)

Dasar hukum fatwa DSN terkait dengan pasar modal tersebut dilandaskan pada firman Allah SWT yang artinya: "Hai orang-orang yang beriman, janganlah kamu saling memakan harta sesamamu dengan jalan yang batil, kecuali dengan jalan perniagaan yang berlaku dengan suka sama suka di antara kamu. Dan janganlah kamu membunuh dirimu. Sesungguhnya Allah adalah Maha Penyayang kepadamu." (QS. An-Nisa [4]: 29).

\section{b. Instrumen Pasar Modal}

Instrumen pasar modal dalam konteks praktis lebih banyak dikenal dengan sebutan sekuritas (securities). Sekuritas atau surat berharga merupakan aset finansial yang menyatakan klaim keuangan. UUPM No. 8 tahun 1995 mendefinisikan surat berharga yang dimaksud adalah surat 
pengakuan hutang, surat berharga komersial, saham, obligasi, tanda bukti hutang, unit penyertaan investasi kolektif, kontrak berjangka atas efek dan setiap derivatif dari efek. Sekuritas diperdagangkan di pasar finansial (financial market) yang terdiri dari pasar modal dan pasar uang.

Pasar modal (capital market) pada prinsipnya merupakan pasar untuk sekuritas jangka panjang. Berbagai sekuritas jangka panjang yang diperdagangkan di pasar modal Indonesia antara lain saham biasa dan saham preferen, obligasi perusahaan dan obligasi konversi, obligasi negara, bukti right, waran, kontrak opsi, kontrak berjangka, dan reksadana (Tandellin, 2017c).

1) Sekuritas di pasar ekuitas.

a) Saham biasa (common stock)

Saham biasa merupakan bentuk penyertaan kepemilikan terhadap suatu perusahaan. Kepemilikan saham pada suatu perusahaan ditunjukkan dengan sertifikat kepemilikan saham.

b) Saham preferen (preferrend stock)

Saham preferen biasanya memberikan pilihan tertentu atas hak pembagian dividen. Jika suatu saat emiten mengalami kerugian maka pemegang saham preferen bisa tidak menerima pembayaran dividen yang sudah ditetapkan sebelumnya. Jadi saham preferen merupakan saham yang memberikan prioritas pilihan kepada pemegangnya (Hadi, 2015d).

c) Bukti right

Bukti right merupakan sekuritas yang memberikan hak kepada pemegang saham lama untuk membeli saham baru perusahaan pada harga tertentu dalam jangka waktu tertentu.

d) Waran

Waran adalah hak untuk membeli saham pada harga tertentu dalam jangka waktu tertentu. Waran tidak saja dapat diberikan kepada pemegang saham lama, tetapi juga sering diberikan kepada pemegang obligasi sebagai pemanis pada saat perusahaan menerbitkan obligasi.

2) Sekuritas di pasar obligasi

Obligasi adalah tanda bukti perusahaan memiliki utang jangka panjang kepada masyarakat di atas 3 tahun. Pihak yang membeli obligasi disebut pemegang obligasi. Pemegang obligasi akan menerima kupon sebagai pendapatan dari obligasi yang dibayarkan setiap 3 bulan atau 6 bulan sekali.

3) Sekuritas di pasar derivatif

Sekuritas derivatif (turunan) adalah aset finansial yang diturunkan dari saham dan obligasi, dan bukan dikeluarkan oleh perusahaan atau pemerintah untuk mendapatkan dana. Ada dua jenis yang terpenting dari sekuritas di pasar derivatif, yaitu:

a) Kontrak berjangka (future contract)

Kontrak berjangka merupakan suatu perjanjian yang dibuat hari ini yang mengharuskan adanya transaksi di masa mendatang.

b) Kontrak opsi (option contract)

Kontrak opsi merupakan kontrak untuk memberikan hak (bukan kewajiban) bagi pemiliknya untuk membeli atau menjual suatu aset tertentu pada harga dan waktu tertentu. 
4) Reksadana (mutual fund)

Reksadana merupakan wadah dan pola pengelolaan modal bagi sekumpulan investor untuk berinvestasi dalam instrumen-instrumen investasi yang ada di pasar dengan cara membeli unit penyertaan reksadana. Dana ini kemudian dikelola oleh manajer investasi ke dalam portofolio investasi

\section{c. Analisis Ekonomi}

Analisis ekonomi adalah analisis yang perlu dilakukan investor dalam penentuan keputusan investasinya. Analisis ini perlu dilakukan karena kecenderungan adanya hubungan yang kuat antara apa yang terjadi pada lingkungan ekonomi makro dan kinerja suatu pasar modal. Pasar modal mencerminkan apa yang terjadi pada perekonomian makro karena nilai investasi ditentukan oleh aliran kas yang diharapkan serta tingkat return yang disyaratkan atas investasi tersebut, kedua hal tersebut sangat dipengaruhi oleh perubahan lingkungan ekonomi makro.

Fluktuasi yang terjadi di pasar modal akan terkait dengan perubahan yang terjadi pada berbagai variabel ekonomi makro. Harga saham merupakan cerminan dari ekspetasi investor terhadap faktor-faktor earning, aliran kas dan tingkat return yang disyaratkan investor, yang artinya ketiga faktor tersebut sangat dipengaruhi oleh kinerja ekonomi makro. Siegel menyimpulkan bahwa ada hubungan yang kuat antara harga saham dan kinerja ekonomi makro, dan menemukan bahwa perubahan pada harga saham selalu terjadi sebelum terjadinya perubahan ekonomi.

Lingkungan ekonomi makro adalah lingkungan yang mempengaruhi operasi perusahaan sehari-hari. Kemampuan investor dalam memahami dan meramalkan kondisi ekonomi makro di masa datang akan sangat berguna dalam pembuatan keputusan investasi yang menguntungkan. Tandelilin merangkum beberapa faktor ekonomi makro yang berpengaruh terhadap investasi di suatu negara adalah tingkat pertumbuhan produk domestik bruto, laju inflasi, tingkat suku bunga, dan nilai tukar mata uang (Tandelilin, 2001c).

Harga saham akan mudah terpengaruh oleh perubahan faktor ekonomi makro karena investor lebih cepat bereaksi. Ketika perubahan faktor ekonomi makro terjadi, investor akan mengkalkulasi dampaknya baik yang positif maupun negatif terhadap kinerja perusahaan beberapa tahun ke depan, kemudian mengambil keputusan untuk membeli atau menjual saham yang bersangkutan. Faktor makro mempengaruhi kinerja perusahaan, sehingga secara fundamental juga akan mempengaruhi harga saham di pasar.

Investor fundamentalis akan memberi nilai saham sesuai dengan kinerja perusahaan saat ini dan prospek kinerja perusahaan di masa datang. Jika kinerjanya meningkat, maka harga saham akan meningkat dan jika kinerjanya menurun, maka harga saham akan menurun (Samsul, 2006). 


\subsubsection{Pasar Modal Syariah}

Pasar modal syariah (Islamic Stock Exchange) adalah kegiatan yang berhubungan dengan perdagangan efek syariah perusahaan publik yang berkaitan dengan efek yang diterbitkannya, serta lembaga profesi yang berkaitan dengannya, dimana semua produk dan mekanisme operasionalnya berjalan tidak bertentangan dengan hukum muamalat islamiyah. Pasar modal syariah dapat juga diartikan sebagai pasar modal yang menerapkan prinsipprinsip islam atau syariah (Haryani dan Serfianto, 2010b).

Langkah awal perkembangan pasar modal syariah di Indonesia dimulai dengan diterbitkannya reksa dana syariah oleh PT Dana Reksa Invesment Management pada 3 Juli 1997 diikuti dengan diterbitkannya obligasi syariah pada akhir 2002. Sedangkan untuk pasar saham syariah di Indonesia mulai dirintis sejak diluncurkannya indeks harga saham berdasarkan prinsip syariah pada tanggal 3 juli 2000, yang disebut sebagai Jakarta Islamic Index (JII) dengan tujuan untuk memandu para investor yang ingin menanamkan dananya secara syariah. Dengan hadirnya indeks tersebut, para pemodal telah disediakan saham-saham yang dapat dijadikan sebagai sarana berinvestasi dengan menggunakan prinsip syariah (Umam, 2013b) Fungsi dari keberadaan pasar modal syariah adalah sebagai berikut :

a. Memungkinkan bagi masyarakat untuk berpartisipasi dalam kegiatan bisnis dengan memperoleh bagian dari keuntungan dan resikonya.

b. Memungkinkan perusahaan meningkatkan modal dari luar untuk membangun dan mengembangkan lini produksinya.

c. Memungkingkan para pemegang saham menjual sahamnya guna mendapatkan likuiditas.

d. Memisahkan operasi kegiatan bisnis dari fluktuasi jangka pendek pada harga saham yang merupakan ciri umum pada pasar modal konvesional.

e. Memungkinkan investasi pada ekonomi yang ditentukan oleh kinerja kegiatan bisnis sebagaimana tercermin pada harga saham. (Mardani, 2017).

\subsubsection{Investasi di Pasar Modal}

Investasi merupakan komitmen atas sejumlah dana atau sumber daya lainnya yang dilakukan pada saat ini dengan tujuan memperoleh sejumlah keuntungan di masa datang. Investasi dapat juga diartikan sebagai tindakan menanamkan sebagian modal yang dimiliki dan biasanya berjangka waktu panjang dengan harapan mendapatkan keuntungan di masa yang akan datang (Tandelilin, 2001d).

Harapan keuntungan tersebut pada dasarnya merupakan kompensasi atas waktu yang harus ditanggung oleh investor dalam berinvestasi. Pada umumnya, investasi dikategorikan menjadi tiga jenis, yaitu real assets, commodity assets, dan financial assets. Dalam hal ini yang dibahas adalah financial assets, khususnya saham.

Menurut Tandelilin, ada 3 hal yang menjadi tujuan investor melakukan investasi :

a. Untuk mendapatkan kehidupan yang lebih baik di masa yang akan datang.

b. Mengurangi tekanan inflasi.

c. Dorongan untuk menghemat pajak. 
Return merupakan alasan utama seseorang untuk berinvestasi. Investasi dipasar modal merupakan salah satu bidang invetasi yang sangat menarik, tetapi tergolong berisiko tinggi. Saham-sahamnya tergolong berisiko tinggi karena sifat komoditinya yang sangat peka terhadap perubahanperubahan yang terjadi, baik perubahan di luar negeri maupun dalam negeri, makro ekonomi, kebijakan pemerintah, dan perusahaan itu sendiri (Tandelilin, 2001e). berikut :

Keuntungan dan kerugian membeli saham bagi pemodal adalah sebagai

\section{a. Keuntungan}

1) Capital gain, yaitu keuntungan dari hasil jual beli saham berupa selisih antara nilai jual yang lebih tinggi daripada nilai beli saham.

2) Dividen, yaitu bagian keuntungan perusahaan yang akan dibagikan kepada pemegang saham. (Hadi, 2015e).

3) Saham perusahaan seperti tanah atau aktiva berharga sejenis, nilainya akan meningkat sejalan dengan waktu dan sejalan dengan perkembangan atau kinerja perusahaan.

4) Saham juga dapat dijaminkan ke bank untuk memperoleh kredit sebagai agunan tambahan dari agunan pokok.

b. Kerugian

1) Capital loss, yaitu kerugian dari hasil jual saham berupa selisih antara nilai jual yang lebih rendah daripada nilai beli saham (Hadi, 2015f)

2) Opportunity loss, yaitu kerugian berupa selisih suku bunga deposito dikurangi dengan total hasil yang diperoleh dari investasi saham.

3) Kerugian karena perusahaan dilikuidasi, tetapi nilai likuidasinya lebih rendah dari harga beli saham.

\subsubsection{Return Saham}

Return saham adalah tingkat keuntungan yang dinikmati oleh pemodal atas suatu investasi saham yang dilakukannya. Setiap investasi baik jangka pendek maupun jangka panjang memiliki tujuan utama untuk mendapatkan keuntungan yang disebut return, baik langsung maupun tidak langsung. Secara sederhana investasi dapat diartikan sebagai suatu kegiatan menempatkan dana pada satu atau lebih dari satu asset selama periode tertentu dengan harapan dapat memperoleh penghasilan atau peningkatan nilai investasi.

Dalam konsep return tidak terlepas dari risiko, karena investor selalu mengharapkan tingkat return yang sesuai atas setiap risiko investasi yang dihadapinya. Return merupakan hasil yang diperoleh dari investasi yang berupa return realisasi (realized return) dan return ekspektasi (expected return). Pada penelitian ini return digunakan pada suatu investasi untuk mengukur hasil keuangan suatu perusahaan.

Return dapat berupa return realisasi yang sudah terjadi atau return yang belum terjadi tetapi diharapkan di masa mendatang. Return realisasi merupakan return yang telah terjadi dan juga berguna sebagai dasar penentuan return ekspektasi (expected return) yang merupakan return yang diharapkan oleh investor di masa mendatang (Hadi, 2015g).

Jogiyanto menjelaskan bahwa terdapat 2 (dua) unsur pokok return total saham, yaitu: capital gain dan dividen. Capital gain merupakan hasil yang diperoleh investor dari selisih antara harga pembelian dengan harga 
penjualan. Artinya jika kurs beli lebih kecil daripada kurs jual maka investor dikatakan memperoleh capital gain, dan sebaliknya disebut capital loss. Sedangkan dividen merupakan hasil yang diperoleh oleh investor akibat memiliki saham perusahaan, yang dapat diterima dalam bentuk kas (cash deviden) maupun dalam bentuk saham (stock deviden).

Dalam penelitian ini, return saham yang dimaksud adalah capital gain atau capital loss yang didefinisikan sebagai selisih dari harga investasi sekarang relatif dengan periode yang lalu (Hartono 2017b).

Faktor-faktor yang mempengaruhi return saham, yaitu :

a. Faktor fundamental

Faktor fundamental adalah faktor yang berkaitan langsung dengan kinerja emiten itu sendiri. Semakin baik kinerja emiten maka semakin besar pengaruhnya terhadap kenaikan harga saham begitu juga sebaliknya. Selain itu keadaan emiten akan menjadi tolak ukur seberapa risiko yang akan ditanggung oleh investor.

b. Faktor Pasar

Faktor pasar merupakan bagaimana kondisi pasar pada saat berlangsungnya transaksi jual beli saham pada pergerakan IHSG.

c. Faktor Makro

Faktor makro merupakan faktor yang berada di luar perusahaan, tetapi mempunyai pengaruh terhadap kenaikan atau penurunan kinerja perusahaan dan dapat mempengaruhi kinerja saham (Sudarsono dan Sudiyatno, 2016b).

\subsubsection{Saham Syariah}

Saham adalah surat berharga yang mempresentasikan penyertaan modal ke dalam suatu perusahaan. Wujud kepemilikan (penyertaan) bahwa para pemegang saham memiliki seperangkat hak seperti hak bersuara dalam RUPS, residual claim dan sejenisnya. Kepemilikan saham pada suatu perusahaan ditunjukkan dengan sertifikat kepemilikan saham. Investor juga memiliki hak terhadap pendapatan dan kekayaan perusahaan apabila investor telah memiliki saham perusahaan setelah dikurangi pembayaran semua kewajiban perusahaan.

Menurut Mas'ud, saham adalah surat tanda pemilikan suatu perusahaan atau bisa juga surat berharga yang menunjukkan bahwa seseorang ikut memiliki sebuah perseroan terbatas. Kepemilikan tersebut menyebabkan timbulnya hak-hak tertentu kepada pemegang saham dalam proporsi tertentu (Mas'ud, 1999). Dapat disimpulkan bahwa saham adalah surat berharga yang dapat diperjualbelikan. Pemegang saham menjadi salah satu pemilik perseroan terbatas dan dapat ikut berpartisipasi dalam modal perusahaan serta mendapatkan dividen jika perusahaan tersebut memperoleh keuntungan.

Saham dikategorikan menjadi dua yaitu saham syariah dan saham non syariah. Perbedaan ini terletak pada kegiatan usaha dan tujuannya. Saham syariah adalah saham-saham perusahaan emiten yang kegiatan usahanya tidak bertentangan dengan syariah Islam atau yang lebih dikenal dengan syariah compliant. Sedangkan saham non syariah adalah saham yang kegiatan usahanya tidak sesuai dengan prinsip syariah Islam. Berdasarkan Peraturan Bapepam-LK Nomor IX.A.13 (Kep-130/BL/2006) tentang Penerbitan Efek Syariah. Pemerintah dan DPR juga telah menerbitkan UU Nomor 19 Tahun 2008 tentang Surat Berharga Syariah Negara. jenis kegiatan utama suatu 
badan usaha yang dimiliki yang bertentangan dengan prinsip-prinsip syariah Islam adalah sebagai berikut :

a. Usaha perjudian dan permainan yang tergolong judi atau perdagangan yang dilarang.

b. Menyelenggarakan jasa keuangan yang menerapkan konsep ribawi (riba), jual beli berisiko yang mengandung gharar dan masyir.

c. Memproduksi, mendistribusikan, memperdagangkan dan atau menyediakan barang atau jasa yang haram karena zatnya (haram li-dzatihi) barang dan atau jasa yang haram bukan karena dzatnya (haram li-ghairihi) yang ditetapkan oleh DSN-MUI, serta barang dan atau jasa yang merusak moral dan bersifat mudarat.

d. Melakukan investasi pada perusahaan yang pada saat transaksi tingkat (nisbah) hutang perusahaan kepada lembaga keuangan ribawi lebih dominan dari modalnya oleh DSN-MUI (Haryani dan Serfianto, 2011b)

Sedangkan kriteria saham yang masuk dalam kategori syariah adalah :

a. Tidak melakukan kegiatan usaha sebagaimana yang diuraikan di atas.

b. Tidak melakukan perdagangan yang tidak disertai dengan penyerahan barang atau jasa dan perdagangan dengan penawaran dan permintaan palsu.

c. Tidak melebihi rasio keuangan sebagai berikut :

1) Total hutang yang berbasis bunga dibandingkan dengan total ekuitas tidak lebih dari $82 \%$ (hutang yang berbasis bunga dibandingkan dengan total ekuitas tidak lebih dari 45\%: 55\%).

2) Total pendapatan bunga dan pendapatan tidak halal lainnya dibandingkan dengan total pendapatan (revenue) tidak lebih dari 10\%. (Sutedi, 2011).

Saham memiliki jenis yang bervariasi. Setiap kelompok juga memilikin ciri khusus. Jenis saham yang dapat dikelompokkan berdasarkan jenis-jenis berikut ini:

a. Jenis Saham Berdasarkan Hak yang melekat pada saham

1) Saham Biasa (Common Stocks), Saham biasa merupakan saham yang paling dikenal masyarakat. Saham biasa juga merupakan yang paling banyak digunakan untuk menarik dana dari masyarakat. Jadi saham biasa paling menarik, baik bagi pemodal maupun emiten.

2) Saham Preferen (Preferred Stocks), Saham preferen merupakan gabungan (hybrid) antara obligasi dan saham biasa karena bisa menghasilkan pendapatan tetap (seperti bunga obligasi), tetapi juga juga bisa tidak mendatangkan hasil seperti yang dikehendaki investor.

b. Jenis Saham Berdasarkan Kepemilikan

1) Saham atas tunjuk (bearer stocks) artinya pada saham tersebut tidak tertulis nama pemilik saham, saham jenis ini sangat mudah dipindah tangankan (dialihkan) kepemilikan sehingga memiliki likuiditas yang lebih tinggi.

2) Saham atas nama (registered stocks) merupakan saham yang ditulis dengan jelas siapa nama pemiliknya, dan cara peralihannya melalui prosedur tertentu.

c. Jenis Saham Berdasarkan Kinerja Perdagangan

1) Saham unggulan (blue chips Stock), Saham-saham dalam kelompok ini adalah saham-saham yang secara nasional dikenal mempunyai historis yang kuat dan bagus. 
2) Saham Pendapatan (income stocks), Saham pendapatan adalah saham yang membayar dividen melebihi jumlah rata-rata pendapatan.

3) Saham bertumbuh (growth stocks), Ciri saham ini adalah memiliki petumbuhan pendapatan yang lebih tinggi dari pertumbuhan beberapa tahun sebelumnya.

4) Saham-saham siklikal (cyclical stocks), Ciri-ciri saham ini adalah memberikan tingkat pengembalian lebih baik dari perubahan tingkat pengembalian pasar secara keseluruhan.

5) Saham spekulatif (speculative stocks), Ciri saham ini adalah perusahaan beroperasi dengan kegiatan yang memiliki risiko usaha tinggi, tetapi memiliki kemungkinan memperoleh keuntungan besar. (inkonsisten dalam memperoleh penghasilan dari tahun ke tahun).

6) Saham-saham bertahan (defensive stocks/ counter cyclical stocks), Ciri sahamsaham ini adalah tetap stabil selama periode resesi.

7) Saham bertumbuh emerging (emerging growth stocks), Saham bertumbuh emerging adalah saham yang dikeluarkan oleh perusahaan yang relatif lebih kecil dan memiliki daya tahan yang kuat meskipun dalam kondisi ekonomi yang kurang mendukung, yang memasuki tahap memperoleh laba dalam jumlah besar sebagai hasil peningkatan volume penjualan dan mempebesar profit marginnya.

d. Jenis saham berdasarkan besaran kapitalisasinya

1) Saham berkapitalisasi besar (big-cap), yaitu saham-saham yang mempunyai kapitalisasi pasar di atas Rp 5 triliun.

2) Saham kapitalisasi menengah (mid-cap), yaitu saham-saham yang memiliki kapitalisasi pasar sebesar Rp.1 s/d 5 triliun.

3) Saham berkapitalisasi kecil (small-cap), yaitu saham yang kapitalisasi pasarnya kurang Rp 1 triliun (Hadi, 2015h)

\subsubsection{Jakarta Islamic Index (JII)}

Indeks syariah atau biasa dikenal dengan Jakarta Islamic Index merupakan kumpulan indeks saham beberapa perusahaan yang kegiatan usahanya tidak bertentangan dengan prinsip syariah. Perhitungan saham syariah pada JII dilakukan PT Bursa Efek Indonesia dengan menggunakan metode perhitungan indeks yang ditetapkan dengan menggunakan metode perhitungan indeks yang ditetapkan dengan bobot kapitalisasi pasar (Market Capitalization Weighed). Perhitungan ini mencakup penyesuaian-penyesuaian yang dilakukan oleh adanya perubahan terhadap data emiten yaitu corporate action. JII menggunakan tanggal perhitungan 1 Januari 1995 dengan nilai awal 100. Dengan indeks ini diharapkan dapat meningkatkan kepercayaan investor untuk mengembangkan investasi secara syariah (Umam, 2013c)

Kriteria investasi Islam berdasarkan fatwa DSN adalah sebagai berikut:

a. Perusahaan yang mendapatkan dana pembiayaan atau sumber dana dari utang tidak lebih dari 30\% dari rasio modalnya.

b. Pendapatan bunga yang diperoleh perusahaan tidak lebih dari $15 \%$.

c. Perusahaan yang memiliki aktiva kas atau piutang yang jumlah piutang dagangnya atau total piutangnya tidak lebih dari 50\%. 
Jakarta Islamic Index merupakan indeks harga saham yang menghitung index harga rata-rata saham untuk jenis kegiatan usaha yang memenuhi kriteria syariah. Berdasarkan fatwa Dewan Syariah Nasional (DSN) No.20 kriteria yang ditetapkan untuk indeks Islam adalah sebagai berikut:

a. Usaha emiten bukan usaha perjudian dan permainan yang tergolong judi atau perdagangan yang dilarang.

b. Bukan merupakan lembaga keuangan ribawi, termasuk bank dan asuransi konvensional.

c. Bukan termasuk usaha memproduksi, mendistribusikan, serta memperdagangkan makanan dan minuman yang haram.

d. Bukan termasuk usaha yang memproduksi, mendistribusikan dan atau menyediakan barang-barang atau jasa yang merusak moral dan bersifat mudarat (Umam, 2013d).

Dari kriteria-kriteria tersebut, saham-saham yang dipilih untuk dapat masuk ke dalam indeks syariah adalah sebagai berikut:

a. Memilih kumpulan saham dengan jenis usaha utama yang tidak bertentangan dengan prinsip syariah dan sudah tercatat lebih dari 3 bulan, kecuali termasuk dalam 10 kapitalisasi besar.

b. Memilih saham berdasarkan laporan keuangan tahunan atau tengah tahun berakhir yang memiliki rasio kewajiban terhadap aktiva maksimal sebesar $90 \%$.

c. Memilih 60 saham dari susunan saham di atas berdasarkan urutan rata-rata kapitalisasi pasar terbesar selama satu tahun terakhir.

d. Memilih 30 saham dengan urutan berdasarkan tingkat likuiditas rata-rata nilai perdagangan regular selama 1 tahun terakhir.

e. Evaluasi terhadap komponen indeks dilakukan setiap enam bulan sekali.

Perubahan pada jenis usaha emiten akan dimonitor secara terus menerus berdasarkan data publik yang tersedia. Perusahaan yang mengubah lini bisnisnya sehingga menjadi tidak konsisten dengan prinsip syariah akan dikeluarkan dari indeks. Sedangkan saham emiten yang dikeluarkan akan diganti oleh saham emiten yang lain. Semua prosedur tersebut bertujuan untuk mengeliminasi adanya saham spekulatif. (Darmadji dan Fakhruddin, 2011b)

\subsubsection{Nilai Tukar (Exchange Rate)}

Nilai tukar merupakan harga sebuah mata uang dari suatu negara yang diukur dalam satuan mata uang negara lainnya. Nilai tukar adalah patokan bank sentral suatu negara untuk membeli atau menjual mata uang asing. Oleh karena itu pembahasan nilai tukar dimulai dari definisinya dan faktor penetapan nilai tukar.

\section{a. Definisi Nilai Tukar}

Nilai Tukar (exchange rate) merupakan catatan harga pasar mata uang asing dalam harga mata uang domestik atau sebaliknya. Nilai tukar uang merepresentasikan tingkat harga pertukaran satu mata uang ke mata uang lainnya yang digunakan dalam berbagai transaksi seperti transaksi perdagangan internasional, turisme, dan investasi internasional, ataupun 
aliran uang jangka pendek antarnegara yang melewati batas-batas geografis ataupun batas-batas hukum (Karim, 2011). Nilai tukar merupakan suatu pembayaran internasional yang memerlukan pertukaran mata uang satu negara menjadi mata uang negara lain yang dapat dilakukan dengan berbagai cara, yang pada hakikatnya hanya menyangkut pertukaran mata uang antara masyarakat yang memiliki satu jenis mata uang dan membutuhkan jenis mata uang lainnya. Nilai tukar suatu mata uang terhadap mata uang lainnya merupakan bagian dari proses valuta asing. Valuta asing atau valas tersebut mengacu pada mata uang asing aktual seperti deposito bank atau surat sanggup bayar yang diperdagangkan. Nilai tukar valuta asing adalah harga dimana pembelian dan penjualan valuta asing berlangsung.

Kenaikan nilai tukar disebut depresiasi atas mata uang dalam negeri. Akibatnya mata uang asing menjadi lebih mahal yang berarti nilai relatif mata uang dalam negeri merosot. Sedangkan turunnya nilai tukar disebut apresiasi mata uang dalam negeri. Akibatnya mata uang asing menjadi lebih murah yang berarti nilai relatif mata uang dalam negeri meningkat (Lipsey, 1992).

\subsubsection{Inflasi}

Menurut Tandelilin, inflasi adalah kecenderungan terjadinya peningkatan harga produk-produk secara keseluruhan. Inflasi merupakan fenomena ekonomi yang luas dampaknya terhadap makroekonomi secara agregat: pertumbuhan ekonomi, keseimbangan eksternal, daya saing, tingkat bunga, dan bahkan distribusi pendapatan.

Tingkat inflasi adalah suatu indikator perubahan kenaikan harga-harga umum. Ada beberapa aspek yang harus diperhatikan mengenai inflasi yaitu:

a. Adanya kecenderungan meningkatnya tingkat harga-harga umum.

b. Kecenderungan meningkatnya harga-harga terjadi secara terus-menerus, dengan demikian peningkatan tingkat harga pada suatu titik waktu tertentu yang disebabkan oleh gejolak apapun belum dapat disebut inflasi.

c. Mencakup pengertian tingkat harga umum yang artinya tingkat harga yang cenderung meningkat tersebut bukan hanya pada tingkat harga satu atau beberapa komoditi saja.

d. Inflasi juga tidak harus berarti bahwa harga-harga berbagai macam barang naik dengan presentase yang sama (Jamli, 2001).

\subsubsection{Risiko Sistematis}

Risiko adalah sebagai bentuk keadaan ketidakpastian tentang suatu keadaan yang akan terjadi nantinya dengan keputusan yang diambil berdasarkan suatu pertimbangan (Tandelilin, 2001j). Menurut Halim dalam konteks portofolio risiko dibedakan menjadi dua, yaitu:

a. Risiko Sistematis (systematic risk)

Risiko Sistematis merupakan risiko yang tidak dapat dihilangkan dengan melakukan diversivikasi, karena fluktuasi risiko ini dipengaruhi oleh faktorfaktor makro yang dapat mempengaruhi pasar secara keseluruhan. Misalnya adanya perubahan tingkat suku bunga, kurs valas, kebijakan pemerintah.

b. Risiko tidak sistematis (unsystematic risk)

Risiko tidak sistematis merupakan risiko yang dapat dihilangkan dengan melakuakn diversifikasi, karena risiko ini hanya ada dalam satu 
perusahaan atau industri tertentu. Fluktuasi risiko ini berbeda-beda antara satu saham dengan saham yang lain. Karena perbedaan itulah maka masingmasing saham memiliki tingkat sensitivitas yang berbeda terhadap setiap perubahan pasar.

Faktor yang mempengaruhinya antara lain, struktur modal, struktur aset, tingkat likuiditas dan tingkat keuntungan. Beta (b) merupakan suatu ukuran tingkat risiko suatu sekuritas didalam hubungannya dengan pasar sekuritas itu sendiri. Jadi Beta digunakan untuk mengukur nondiversifiable risk atau market risk (Nugroho dan Sukhemi, 2015).

Beta suatu sekuritas dapat dihitung dengan teknik estimasi yang menggunakan data historis. Beta yang dihitung berdasarkan data historis selanjutnya dapat digunakan untuk mengestimasi beta dimasa datang. Beta historis dapat dihitung dengan menggunakan data historis berupa data pasar (return sekuritas dan return pasar), data akuntansi (laba-laba perusahaan dan laba indeks pasar). Beta yang dihitung dengan data pasar disebur beta pasar, beta pasar dapat diestimasi dengan mengumpulkan nilai-nilai historis return dari sekuritas dan return dari pasar selama periode tertentu, misal selama 60 bulan untuk return bulanan atau 200 hari untuk return harian (Hartono, 2017c)

\subsubsection{Konsep Return dan Risiko}

Investasi adalah suatu bentuk penanaman dana atau modal untuk menghasilkan kekayaan, yang akan memberikan keuntungan tingkat pengembalian (return) baik pada masa sekarang dan di masa datang. Harapan keuntungan di masa datang merupakan kompensasi atas waktu dan risiko yang terkait dengan investasi yang dilakukan. Dalam konteks investasi harapan keuntungan tersebut sering sebagai return (Tandelilin, 2001g)

Return merupakan salah satu faktor yang memotivasi investor untuk berinteraksi dan juga merupakan imbalan atas keberanian investor dalam menanggung risiko atas investasi yang dilakukannya. Sumber-sumber return investasi terdiri dari dua komponen utama, yaitu yield dan capital gain (loss). Yield merupakan komponen return yang mencerminkan aliran kas atau pendapatan yang diperoleh secara periodik dari suatu investasi. Jika berinvestasi pada sebuah obligasi atau bunga mendepositokan uang di bank, maka besarnya yield ditunjukkan dari bunga obligasi atau bunga deposito yang diterima. Jika berinvestasi dalam saham, yield ditunjukkan oleh besarnya dividen yang kita peroleh. Sedangkan capital gain (loss) sebagai komponen kedua dari return merupakan kenaikan (penurunan) harga suatu surat berharga (saham atau obligasi), yang bisa memberikan keuntungan (kerugian) bagi investor (Tandelilin, 2001h)

Pada dasarnya tujuan investor dalam berinvestasi adalah memaksimalkan return. Return dapat berupa return realisasi ataupun return ekspektasi. Return realisasi merupakan return yang telah terjadi yang dihitung berdasarkan data historis. Return realisasi penting karena digunakan sebagai salah satu pengukur kinerja dari perusahaan serta sebagai dasar penentuan return ekspektasi (expected return) untuk mengukur risiko di masa yang akan datang (Hadi,2015i)

Di samping memperhitungkan return, investor juga perlu mempertimbangkan tingkat risiko suatu investasi sebagai dasar pembuatan 
keputusan investasi. Risiko investasi sendiri merupakan ketidaksesuaian antara expected return dengan return aktualnya (actual return). Artinya, risiko merupakan penyimpangan dari fakta return yang diterima (actual return). Untuk itu, menghitung risiko investasi dapat ditentukan dari tingkat penyimpangan return yang diharapkan (Hartono,2017c)

Ada beberapa sumber risiko yang bisa mempengaruhi besarnya risiko investasi antara lain: risiko suku bunga, risiko pasar, risiko inflasi, risiko bisnis, risiko finansial, risiko likuiditas, risiko nilai tukar, risiko negara, serta masih banyak lagi sumber risiko (Tendelilin, 2001i) Untuk menurunkan risiko investasi, investor perlu melakukan diversifikasi. Diversifikasi menunjukkan bahwa investor perlu membentuk portofolio penanaman dana sedemikian rupa hingga risiko dapat diminimalkan tanpa mengurangi return yang diharapkan. Mengurangi risiko tanpa mengurangi return adalah tujuan investor dalam berinvestasi.

Teori portofolio (portfolio) lahir dari seseorang yang bernama Henry Markowitz. Dasar pemikiran dibentuknya portofolio seperti yang dikatakan Markowitz yaitu: "do not put all eggs in one basket" (janganlah menaruh semua telur ke dalam satu keranjang). Karena jika keranjang tersebut jatuh, maka semua telur yang ada dalam keranjang tersebut akan pecah. Begitu pula dengan investasi yang dilakukan jangan menanamkan seluruh dana dalam satu bentuk investasi, karena ketika investasi tersebut gagal, maka seluruh dana yang tertanam kemungkinan tidak akan kembali. Teori portofolio yang diperkenalkan oleh Markowitz ini telah mengajarkan konsep diversifikasi portofolio secara kuantitatif. Investor dalam melakukan investasi tidak hanya memilih satu saham saja tetapi melakukan kombinasi. Alasan melakukan kombinasi saham, supaya investor bisa meraih return yang optimal dan sekaligus bisa memperkecil risiko melalui diversifikasi. Meskipun telah melakukan diversifikasi investor tidak akan bisa menghilangkan risiko portofolio. Hal yang bisa dilakukan adalah mengurangi risiko portofolio. Investor melakukan diversifikasi risiko investasi dalam berbagai portofolio dikarenakan hasil yang diharapkan dari setiap sekuritas dapat saling menutup (Musthafa, 2017a).

Teori portofolio juga menunjukkan bahwa apabila pemodal melakukan diversifikasi dengan baik, maka akan ada bagian risiko yang dapat dihilangkan dengan diversifikasi. Bagian risiko ini yang disebut risiko tidak sistematis. Sedangkan bagian yang tidak dihilangkan dengan diversifikasi disebut sebagai risiko sistematis.

Ada dua cara yang dapat dilakukakn oleh investor dalam mencapai portofolio yang efisien, diantaranya:

a. Bersedia menerima risiko minimum, maka akan mendapatkan penghasiln tertentu.

b. Bersedia menerima risiko tertentu, maka akan mendapatkan penghasilan maksimum. (Musthafa,2017b)

\subsubsection{BI Rate}

BI Rate didefinisikan sebagai suku bunga kebijakan yang mencerminkan sikap atau stance kebijakan moneter yang ditetapkan oleh Bank Indonesia dan diumumkan kepada publik. BI rate diumumkan oleh Dewan Gubernur Bank Indonesia setiap Rapat Dewan Gubernur bulanan dan 
diimplementasikan pada operasi moneter yang dilakukan Bank Indonesia melalui pengelolaan likuiditas di pasar uang untuk mencapai sasaran operasional kebijakan moneter.

Bank Indonesia pada umumnya akan menaikkan BI rate apabila inflasi ke depan diperkirakan melampaui sasaran yang telah ditetapkan, sebaliknya Bank Indonesia akan menurunkan BI rate apabila inflasi ke depan diperkirakan berada di bawah sasaran yang telah ditetapkan. Kenaikan inflasi disebabkan karena jumlah uang yang beredar terlalu banyak. Hal tersebut membuat Bank Indonesia menaikkan tingkat BI rate. Kenaikan BI rate mendorong masyarakat untuk menabung sehingga jumlah uang yang beredar berkurang dan dapat menurunkan tingkat inflasi. Sukirno menyatakan "Suku bunga adalah persentasi pendapatan yang diterima oleh para penabung dari tabungan uang yang disisihkannya". "Suku bunga yang tinggi mengurangi nilai kini dari arus kas mendatang, sehingga daya tarik peluang investasi menjadi turun" (Afiyati, 2018b). Pada penelitian ini data BI rate yang digunakan adalah data bulanan pada Bank Indonesia dan Badan Pusat Statistik mulai Januari 2015 hingga Desember 2018 yang dinyatakan dalam prosentase (\%)

\subsection{Metode Penelitian}

\subsubsection{Jenis dan Pendekatan}

Berdasarkan hubungan variabel terhadap objek yang diteliti lebih bersifat sebab akibat atau kausal. Sugiyono menyatakan penelitian kausal adalah penelitian yang bertujuan untuk mengetahui hubungan antara dua variabel atau lebih yang mempunyai hubungan sebab akibat terhadap variable lainnya (Sugiyono, 2014a), Jenis penelitian ini adalah penelitian asosiatif, karena peneliti ingin menjelaskan kedudukan variabel-variabel yang diteliti. Penelitian asosiatif pada umumnya dilakukan untuk mengetahui hubungan atau pengaruh antara dua variabel atau lebih. Penelitian ini merupakan bagian dari peneletian asosiatif yaitu termasuk penelitian kausal. Penelitian kausal adalah penelitian yang bertujuan untuk mengetahui pengaruh antar variable (Sugiyono, 2014b). Artinya dengan jenis penelitian tersebut peneliti bisa mengetahui faktor-faktor yang dapat mempengaruhi return saham syariah di Jakarta Islamic Index (JII).

Penelitian ini menggunakan pendekatan penelitian kuantitatif. Pendekatan penelitian kuantitatif yaitu metode penelitian yang berlandaskan pada filsafat positivisme yang digunakan untuk meneliti pada populasi atau sampel tertentu. Peneliti melakukan penelitian dengan menggunakan pendekatan kuantitatif karena memiliki tujuan untuk menguji teori, membangun fakta, menunjukkan pengaruh antar variabel, memberikan deskripsi statistik, dan meramalkan hasilnya (Sugiyono,2014c).

\subsubsection{Populasi dan Sampel}

\section{Populasi}

Populasi merupakan wilayah generalisasi yang terdiri atas objek atau subjek yang mempunyai kuantitas dan karakteristik tertentu yang ditetapkan oleh peneliti untuk dipelajari dan kemudian ditarik kesimpulannya. Jadi populasi bukan hanya orang tetapi juga benda-benda alam yang lain. Populasi juga bukan sekedar jumlah yang ada pada objek atau subjek yang dipelajari, tetapi meliputi seluruh karakteristik atau sifat yang dimiliki oleh objek atau 
subjek tersebut (Sugiyono, 2014d). Populasi dalam penelitian ini adalah saham syariah di Indonesia yang telah terdaftar di Jakarta Islamic Index (JII) selama periode 2015-2018. Jumlah populasi yang digunakan dalam penelitian ini adalah 240 perusahaan terbuka yang memiliki saham syariah yang terdaftar dalam Jakarta Islamic Index di Bursa Efek Indonesia periode 20152018.

\section{Sampel}

Berdasarkan populasi tersebut dapat ditentukan sampel yang menjadi objek penelitian ini. Sampel adalah bagian dari karakteristik yang dimiliki oleh populasi tersebut. Dalam penelitian ini, metode yang digunakan untuk penarikan sampel adalah sampel purposive (purposive sampling). Sampel purposive adalah cara penentuan atau penarikan sampel dengan kriteriakriteria/pertimbangan-pertimbangan tertentu. Pertimbangan tersebut didasarkan pada kepentingan atau tujuan penelitian yang berguna untuk memberikan informasi yang maksimal (Sugiyono, 2014e)

Perusahaan terbuka yang dijadikan sampel oleh peneliti adalah perusahaan yang mampu (Suharyadi dan Purwanto, 2019b) memberikan informasi yang dibutuhkan dan apabila memenuhi kriteria-kriteria sebagai berikut:

a. Perusahaan yang listing di JII selama periode 2015 hingga 2018 dengan ketentuan-ketentuan sebagai berikut:

1) Perusahaan-perusahaan tersebut harus memiliki jenis usaha yang prinsip utamanya adalah syariah dan minimal harus sudah berjalan selama 3 bulan, kecuali termasuk dalam 10 kapitalisasi pasar terbesar.

2) Harus memiliki saham yang rasio kewajiban terhadap aktiva maksimalnya sebesar 90\% dan harus sesuai berdasarkan laporan keuangan yang dibuat di pertengahan tahun atau akhir tahun.

3) Harus memiliki mininimal 60 saham dari Daftar Efek Syariah yang berdasarkan urutan kapitalisasi pasar terbesar selama 1 tahun terakhir dan 30 saham dengan urutan tingkat likuiditas yaitu nilai transaksi di pasar reguler selama 1 tahun terakhir.

b. Perusahaan yang terdaftar dalam JII selama 4 tahun berturut-turut mulai tahun 2015 hingga 2018.

Tabel 1. Kriteria Perusahaan selama 2015-2018

\begin{tabular}{|c|c|c|c|c|}
\hline No. & Kriteria & $\begin{array}{c}\text { Melanggar } \\
\text { Kriteria }\end{array}$ & $\begin{array}{c}\text { Memenuhi } \\
\text { Kriteria }\end{array}$ & Total Sampel \\
\hline 1, & $\begin{array}{c}\text { Perusahaan yang } \\
\text { listing di JII } \\
\text { selama periode } \\
2015-2018\end{array}$ & 30 & 30 \\
\hline 2. & $\begin{array}{c}\text { Perusahaan yang } \\
\text { terdaftar di JII } \\
\text { selama 4 tahun } \\
\text { berturut-turut } \\
\text { mulai 2015-2018 }\end{array}$ & 13 & 17 & 17 \\
\hline 3. & $\begin{array}{c}\text { Jumlah Sampel } \\
\text { yang memenuhi } \\
\text { kriteria }\end{array}$ & & & 17 \\
\hline 4. & $\begin{array}{c}\text { Tahun } \\
\text { Pengamatan }\end{array}$ & & & 4 \\
\hline
\end{tabular}




\begin{tabular}{|c|c|c|c|c|}
\hline 5. & $\begin{array}{c}\text { Jumlah Total } \\
\text { Sampel }\end{array}$ & & 68 \\
\hline
\end{tabular}

Sumber: IDX tahun 2018, data diolah

Dari kriteria yang ditetapkan, maka dari 30 perusahaan terbuka yang terdaftar dalam JII yang dijadikan sampel penelitian ada 17 perusahaan.

Tabel. 2

Perusahaan Terbuka yang Terdaftar di JII 2015-2018

\begin{tabular}{|c|c|c|}
\hline No. & Kode Emiten & Nama Perusahaan \\
\hline 1 & ADRO & Adaro Energy Tbk \\
\hline 2 & AKRA & AKR Corporindo Tbk \\
\hline 3 & ASII & Astra International Tbk \\
\hline 4 & BSDE & Bumi Serpong Damai Tbk \\
\hline 5 & ICBP & Indofood CBP Sukses Makmur Tbk \\
\hline 6 & INCO & Indofood Sukses Makmur Tbk \\
\hline 7 & INDF & Pewrusahaan Gas Negara (persero) Tbk \\
\hline 8 & KLBF & PP (Persero) Tbk \\
\hline 9 & PGAS & Summarecon Agusng Tbk \\
\hline 10 & PTPP & Sawit Sumber Mas Tbk \\
\hline 11 & SMGR & Telekom Indonesia (Persero) Tbk \\
\hline 12 & SMRA & United Tractor Tbk \\
\hline 13 & SSMS & Unilever Indonesia Tbk \\
\hline 14 & TLKM & Wiajaya Karya (Persero) Tbk \\
\hline 15 & UNTR & \\
\hline 16 & UNVR \\
\hline 17 & WIKA & \\
\hline
\end{tabular}

Sumber : IDX 2018

\section{HASIL DAN PEMBAHASAN}

\subsection{Hasil Analisis Data}

Uji hipotesis digunakan untuk menguji hipotesis penelitian yang telah dirumuskan sebelumnya, yaitu untuk mengetahui pengaruh variabel exchange rate, Inflasi, Resiko Sistematis, BI Rate terhadap Return Saham Syariah di JII periode 2015-2018.

\subsection{Pembahasan}

\subsubsection{Diskripsi Data Variabel}

\section{a. Variabel Return Saham (Y)}

Dari tabel 4.6 di atas data diketahui bahwa nilai maksimum return saham sebesar 0,53 dan nilai minimum return saham sebesar -0,55. Rata-rata nilai return saham (mean) sebesar -0.0201 dan standar deviasi sebesar 0,22173. Dari data tersebut dapat dilihat bahwa nilai standar deviasi lebih besar daripada nilai rata-rata yaitu $0,22173>-0.0201$, berarti sebaran nilai saham tidak baik. Return saham tertinggi terjadi pada perusahaan Indofood Tbk. sebesar 0,53, sedangkan return saham terendah terjadi pada perusahaan Vale Indonesia Tbk. sebesar -0,55.

\section{b. Variabel Exchange Rate (X1)}

Berdasarkan hasil pengujian pada tabel 4.6 di atas diketahui bahwa Exchange Rate ditunjukkan dengan proksi EXCHANGE RATE, memiliki nilai minimum 
sebesar 13329.83 yang terjadi pada tahun 2016 dan nilai maksimum sebesar 14267.33 yang terjadi pada tahun 2018. Sedangkan nilai rata-rata (mean) EXCHANGE RATE sebesar 13613.2275 dan standar deviasi sebesar 383.16984. Nilai deviasi lebih kecil daripada nilai rata-rata yaitu 383.16984 < 13613.2275, menunjukkan sebaran Exchange Rate dalam kondisi baik.

\section{c. Variabel Inflasi (X2)}

Berdasarkan hasil pengujian pada tabel 4.6 di atas diketahui bahwa Tingkat Inflasi ditunjukkan dengan proksi INFLASI, memiliki nilai minimum 80 sebesar 3,02\% yang terjadi pada tahun 2016 dan nilai maksimum sebesar $3,61 \%$ yang terjadi pada tahun 2017. Sedangkan nilai rata-rata (mean) INFLASI sebesar $3.2775 \%$ dan standar deviasi sebesar $0.22744 \%$. Nilai deviasi lebih kecil daripada nilai rata-rata yaitu $0.22744<3.2775$, menunjukkan sebaran Tingkat Inflasi dalam kondisi baik.

\section{d. Variabel Risiko Sistematis (X3)}

Berdasarkan hasil pengujian pada tabel 4.6 di atas diketahui bahwa Risiko Sistematis ditunjukkan dengan proksi RISIKO SISTEMATIS, memiliki nilai minimum sebesar -1.89 yang terjadi pada perusahaan Wijaya Karya (Persero) Tbk tahun 2017 dan nilai maksimum sebesar 2.73 yang terjadi pada perusahaan Bumi Serpong Damai Tbk tahun 2015. Sedangkan nilai rata-rata (mean) RISIKO SISTEMATIS sebesar 0.9883 dan standar deviasi sebesar 0.60360 . Nilai deviasi lebih kecil daripada nilai rata-rata yaitu $0.60360<$ 0.9883, menunjukkan sebaran Risiko Sistematis dalam kondisi baik.

\section{e. Variabel BI Rate (X4)}

Berdasarkan hasil pengujian pada tabel 4.6 di atas diketahui bahwa BI rate ditunjukkan dengan proksi BI RATE, memiliki nilai minimum sebesar 4,56 yang terjadi pada tahun 2017 dan nilai maksimum sebesar 7,50 yang terjadi pada tahun 2015. Sedangkan nilai rata-rata (mean) BI RATE sebesar 5.1850 dan standar deviasi sebesar 0.40708. Nilai deviasi lebih kecil daripada nilai rata-rata yaitu $0.40708<5.1850$, menunjukkan sebaran Tingkat Suku Bunga BI Rate dalam kondisi baik.

\subsubsection{Uji Asumsi Klasik}

\section{a. Uji Normalitas}

Grafik histogram memberikan pola distribusi normal sehingga grafik tersebut menunjukkan bahwa model regresi memenuhi asumsi normalitas. Sedangkan grafik normal plot terlihat titik-titik menyebar di sekitar garis diagonal, serta penyebarannya mengikuti garis diagonal. Sehingga grafik tersebut menunjukkan bahwa model regresi memenuhi asumsi normalitas.

\section{b.Uji Heteroskedastisitas}

Pengujian heteroskedastisitas dilakukan dengan membuat scatterplot (alur sebaran) antara residual dan nilai prediksi dari variabel terikat yang telah distandarisasi. Hasilnya titik-titik data tidak membentuk pola tertentu dan data menyebar di atas dan di bawah angka 0 pada sumbu Y. Maka dari itu dapat disimpulkan tidak terjadi gangguan asumsi heteroskedastisitas yang artinya model regresi ini sudah baik.

\section{c.Uji Autokorelasi}

Uji autokorelasi dalam suatu model regresi dilakukan melalui pengujian dengan uji Run test. Hasilnya diketahui nilai Asymp.Sig. (2-tailed) sebesar 0.222. Nilai tersebut lebih besar dari nilai signifikan 0.05, maka dapat disimpulkan bahwa tidak terdapat masalah autokorelasi. 


\section{d.Uji Multikolinearitas}

Cara melihat ada atau tidaknya multikolinearitas dilihat dari nilai tolerance dan nilai variance inflation factor (VIF). Hasilnya diketahui nilai tolerance untuk variabel Exchange rate adalah 0.590 , variabel inflasi adalah 0.264 , variabel risiko sistematis adalah 0.902 , variabel BI rate adalah 0.274 yang mana lebih besar dari 0.10. Sementara nilai VIF untuk variabel Exchange rate adalah 1.696, variabel inflasi adalah 3.795, variabel risiko sistematis adalah 1.109, variabel BI rate adalah 3.655 yang mana kurang dari 10.00. Hasil perhitungan nilai VIF dari ketiga variabel tidak ada yang lebih dari 10.00, maka mengacu pada dasar pengambilan keputusan dalam uji multikolinearitas dapat disimpulkan bahwa tidak terjadi gejala multikolinearitas dalam model regresi.

\subsubsection{Teknik Analisis Data}

\section{a. Analisis Regresi Linear Berganda}

Persamaan regresi linier berganda dalam penelitian ini menggunakan koefisien beta tidak standar (Unstandardized Coefficients). Hal ini dikarenakan masingmasing variabel memiliki satuan dan berfungsi untuk menjelaskan besarnya koefisien regresi variabel bebas dalam menerangkan variabel terikatnya, rumusnya:

\section{$\mathrm{Y}=6.235-0.011 \mathrm{X} 1-0.573 \mathrm{X} 2+0.091 \mathrm{X} 3-0.291 \mathrm{X} 4+\mathrm{e}$}

Berdasarkan nilai koefisien regresi dari masing-masing variabel yang mempengaruhi Return Saham Syariah (Y) dengan menggunakan tingkat signifikansi $=0.05$ dapat diinterpretasikan sebagai berikut:

a. Nilai konstanta dari hasil penelitian menunjukkan nilai yang positif yaitu 6.235, artinya bahwa jika tidak ada pengaruh dari variabel bebas seperti nilai exchange rate, inflasi, risiko sistematis dan BI rate maka variabel terikat Return Saham Syariah memiliki nilai sebesar 6.235.

b. Nilai koefisien variabel exchange rate sebesar -0.011 menunjukkan arah hubungan negatif atau berlawanan arah antara exchange rate dengan perubahan Return Saham Syariah. Artinya bahwa jika variabel exchange rate turun 1 satuan maka Return Saham Syariah akan naik sebesar 0.011, begitu juga sebaliknya.

c. Nilai koefisien variabel inflasi sebesar -0.573 menunjukkan arah hubungan negatif atau berlawanan arah antara inflasi dengan perubahan Return Saham Syariah. Artinya bahwa jika variabel inflasi turun 1 satuan maka Return Saham Syariah akan naik sebesar 0.573 , begitu juga sebaliknya.

d. Nilai koefisien variabel risiko sistematis sebesar 0.091 menunjukkan arah hubungan positif antara risiko sistematis dengan perubahan Return Saham Syariah. Artinya bahwa jika variabel risiko sistematis naik 1 satuan maka Return Saham Syariah akan naik pula sebesar 0.091, begitu juga sebaliknya.

e. Nilai koefisien variabel BI rate sebesar -0.291 menunjukkan arah hubungan negatif antara BI rate dengan perubahan Return Saham Syariah. Artinya bahwa jika variabel BI rate turun 1 satuan maka Return Saham Syariah akan naik sebesar 0.291 , begitu juga sebaliknya.

f. Koefisien e atau eror menunjukkan bahwa terdapat variabel lain yang mempengaruhi Return Saham Syariah yang tidak dimasukkan dalam penelitian ini.

\section{b. Analisis Koefisien Determinasi (R2)}

Hasilnya diketahui nilai koefisien determinasi (Adjusted R Square) sebesar 0.148 atau sama dengan $14.8 \%$. Nilai tersebut mengandung arti bahwa nilai exchange rate, inflasi, risiko sistematis dan BI rate berpengaruh terhadap Return Saham 
Syariah sebesar 14.8\%. Sedangkan sisanya yaitu $85.2 \%$ dipengaruhi oleh variabel lain di luar model regresi ini.

\section{Uji Parsial (Uji t)}

Pengujian regresi ini menggunakan pengujian dua arah (two tailed test). Untuk mendapatkan nilai ttabel menggunakan $\alpha=5 \%$ dengan derajat bebas ( $\mathrm{df}$ ) $=\mathrm{n}-\mathrm{k}-$ $1=68-4-1=63$. Taraf signifikansi dua pihak adalah 2.5\% (0.025), maka diperoleh nilai $t$ tabel sebesar 1.998. diketahui pengaruh variabel independen secara parsial terhadap variabel dependen adalah sebagai berikut:

1. Pengaruh exchange rate terhadap Return Saham Syariah

Diketahui nilai koefisien regresi dari variabel exchange rate (X1) yaitu -0.011 yang mempunyai standard error 0.009. Dari kedua tersebut menghasilkan thitung sebesar -2.482 dengan signifikansi sebesar 0.016. Nilai t-hitung $>$ t-tabel $(2.482>$ 1.998) dan tingkat signifikan $0.016<0.05$. Sehingga dapat disimpulkan bahwa variabel exchange rate berpengaruh secara negatif dan signifikan terhadap Return Saham Syariah. Dengan demikian hipotesis alternatif (Ha1) yang menyatakan "Exchange Rate berpengaruh secara negatif dan signifikan terhadap Return Saham Syariah" diterima.

2.Pengaruh inflasi terhadap Return Saham Syariah

Diketahui nilai koefisien regresi dari variabel inflasi (X1) yaitu -0.573 yang mempunyai standard error 0.220. Dari kedua tersebut menghasilkan thitung sebesar -2.600 dengan signifikansi sebesar 0.012. Nilai t-hitung $>$ t-tabel $(2.600>$ 1.998 ) dan tingkat signifikan $0.012<0.05$. Sehingga dapat disimpulkan bahwa variabel inflasi berpengaruh secara negatif dan signifikan terhadap Return Saham Syariah. Dengan demikian hipotesis alternatif (Ha2) yang menyatakan "Tingkat Inflasi berpengaruh secara negatif dan signifikan terhadap Return Saham Syariah" diterima.

3. Pengaruh risiko sistematis terhadap Return Saham Syariah

Diketahui nilai koefisien regresi dari variabel risiko sistematis (X3) yaitu 0.091 yang mempunyai standard error 0.045. Dari kedua tersebut menghasilkan thitung sebesar 2.038 dengan signifikansi sebesar 0.046. Nilai t-hitung > t-tabel $2.038>$ 1.998) dan tingkat signifikan $0.046<0.05$. Sehingga dapat disimpulkan bahwa variabel risiko sistematis berpengaruh secara positif dan signifikan terhadap Return Saham Syariah. Dengan demikian hipotesis alternatif (Ha3) yang menyatakan "Risiko Sistematis berpengaruh secara negatif dan signifikan terhadap Return Saham Syariah" diterima, hanya saja tanda tidak sesuai dengan hipotesis.

4. Pengaruh BI rate terhadap Return Saham Syariah

Diketahui nilai koefisien regresi dari variabel BI rate yaitu -0.291 yang mempunyai standard error 0.121. Dari kedua tersebut menghasilkan thitung sebesar -2.412 dengan signifikansi sebesar 0.019. Nilai t-hitung $>$ t-tabel $(2.412>$ 1.998) dan tingkat signifikan $0.019<0.05$. Sehingga dapat disimpulkan bahwa variabel BI rate berpengaruh secara negatif dan signifikan terhadap Return Saham Syariah. Dengan demikian hipotesis alternatif (Ha4) yang menyatakan "BI Rate berpengaruh secara negatif dan signifikan terhadap Return Saham Syariah" diterima.

\section{d. Uji Simultan (Uji F)}

Uji $\mathrm{F}$ digunakan untuk menunjukkan apakah semua variabel independen (exchange rate, inflasi, risiko sistematis dan BI rate) yang dimasukkan dalam model penelitian mempunyai pengaruh secara bersama-sama terhadap variabel 
dependen (Return Saham Syariah). diketahui bahwa nilai F-hitung sebesar 2.810 dan nilai signifikansi sebesar 0.033. Pengujian dilakukan pada $\alpha=5 \%$, df-1 (jumlah variabel-1) atau 5-1= 4 sedangkan df2 (n-k-1) atau 68-4-1 = 63 maka Ftabel diperoleh sebesar 2.52. Dapat disimpulkan bahwa secara simultan nilai Fhitung > F-tabel $(2.810>2.52)$, dengan nilai signifikansi 0.033 yang mana kurang dari 0.05 maka hipotesis alternatif (Ha5) diterima, artinya dengan demikian terdapat pengaruh yang signifikan antara variabel bebas (X) yaitu variabel exchange rate, inflasi, risiko sistematis dan BI rate terhadap variabel terikat (Y) yaitu Return Saham Syariah sehingga uji model diterima.

\section{PENUTUP}

Penelitian ini bertujuan untuk mengetahui pengaruh Exchange Rate, Inflasi, Risiko Sistematis dan BI Rate terhadap Return Saham Syariah di JII Uakarta Islamic Index) periode 2015-2018. Berdasarkan analisis-analisis yang telah dilakukan terhadap hipotesis, maka dapat ditarik kesimpulan sebagai berikut:

1. Hasil pengujian yang pertama diperoleh bahwa ada pengaruh yang signifikan antara exchange rate terhadap return saham syariah. Diketahui nilai koefisien regresi dari variabel exchange rate (X1) yaitu -0.011 yang mempunyai standard error 0.009. Dimana menghasilkan thitung sebesar -2.482 dengan signifikansi sebesar 0.016. Nilai t-hitung $>$ t-tabel $(2.482>1.998)$ dan tingkat signifikan $0.016<0.05$. Sehingga dapat disimpulkan bahwa variabel exchange rate berpengaruh secara negatif dan signifikan terhadap Return Saham Syariah secara parsial. Berarti hipotesis alternatif (Ha1) diterima.

2. Hasil pengujian yang kedua diperoleh bahwa ada pengaruh yang signifikan antara inflasi terhadap return saham syariah. Diketahui nilai koefisien regresi dari variabel inflasi (X1) yaitu -0.573 yang mempunyai standard error 0.220 . Dimana menghasilkan thitung sebesar -2.600 dengan signifikansi sebesar 0.012 . Nilai t-hitung $>$ t-tabel $(2.600>1.998)$ dan tingkat signifikan $0.012<$ 0.05. Sehingga dapat disimpulkan bahwa variabel inflasi berpengaruh secara negatif dan signifikan terhadap Return Saham Syariah secara parsial. Berarti hipotesis alternatif ( $\mathrm{Ha} 2)$ diterima.

3. Hasil pengujian yang ketiga diperoleh bahwa ada pengaruh yang signifikan antara risiko sistematis terhadap return saham syariah. Diketahui nilai koefisien regresi dari variabel risiko sistematis (X3) yaitu 0.091 yang mempunyai standard error 0.045. Dimana menghasilkan thitung sebesar 2.038 dengan signifikansi sebesar 0.046. Nilai t-hitung $>$ t-tabel $(2.038>1.998)$ dan tingkat signifikan $0.046<0.05$. Sehingga dapat disimpulkan bahwa variabel risiko sistematis berpengaruh secara positif dan signifikan terhadap Return Saham Syariah secara parsial. Berarti hipotesis alternatif (Ha3) diterima, hanya saja tanda tidak sesuai dengan hipotesis.

4. Hasil pengujian yang keempat diperoleh bahwa ada pengaruh yang signifikan antara BI rate terhadap return saham syariah. Diketahui nilai koefisien regresi dari variabel BI rate yaitu -0.291 yang mempunyai standard error 0.121 . Dimana menghasilkan thitung sebesar -2.412 dengan signifikansi sebesar 0.019 . Nilai t-hitung $>$ t-tabel $(2.412>1.998)$ dan tingkat signifikan $0.019<$ 0.05. Sehingga dapat disimpulkan bahwa variabel BI rate berpengaruh secara negatif dan signifikan terhadap Return Saham Syariah secara parsial. Berarti hipotesis alternatif (Ha4) diterima. 
5. Hasil perhitungan dengan menggunakan SPSS versi 23 dapat diketahui bahwa nilai F-hitung sebesar 2.810 dan nilai signifikansi sebesar 0.033. Dapat disimpulkan bahwa secara simultan nilai F-hitung $>$ F-tabel $(2.810>2.52)$ dengan nilai signifikansi 0.033 yang mana kurang dari 0.05 , maka terdapat pengaruh yang signifikan antara variabel bebas (X) yaitu variabel exchange rate, inflasi, risiko sistematis dan BI rate terhadap variabel terikat (Y) yaitu Return Saham Syariah. Berarti hipotesis alternatif (Ha5) diterima. 


\section{DAFTAR PUSTAKA}

Afiyati, Hidaya Tri dan Topowijono, (2018). "Pengaruh Inflasi, Bi Rate dan Nilai Tukar Terhadap Return Saham (Studi Pada Perusahaan Subsektor Food \& Beverages yang Terdaftar di Bursa Efek Indonesia Periode 2013-2016)." Jurnal Administrasi Bisnis (JAB), Vol. 61, No. 2, (2018) - $2 \quad$ Mei, 2019 https://administrasibisnis.studentjournal.ub.ac.id

Al Arif, M. Nur Rianto. (2010), Teori Makroekonomi Islam. Alfabeta, Bandung.

Al-Quran Surat An-Nisaa Ayat 29 (2010), Al Qur'an Tajwid dan Terjemahnya. Diponegoro, Bandung.

Boediono, (2010). Ekonomi Moneter Edisi Ketiga. BPFE, Yogyakarta.

Bungin, Burhan (2005). Metodologi Penelitian Kuantitatif Edisi Kedua. Prenada Media Group, Jakarta.

Darmadji, Tjiptono, dan Hendy M. Fakhruddin, (2011), Pasar Modal di Indonesia. Salemba Empat, Jakarta.

Darmawi, Herman, (2017), Manajemen Risiko Edisi 2. PT Bumi Aksara, Jakarta.

Ghozali, Imam, (2013). Aplikasi Analisis Multivariate dengan Program IBM SPSS 23. Badan Penerbit Universitas Diponegoro, Semarang.

Hadi, Nor (2015). Pasar Modal Edisi 2. Graha Ilmu, Yogyakarta.

Hartono, Jogiyanto (2017). Teori Portofolio dan Analisis Investasi Edisi Kesebelas. BPFE, Yogyakarta.

Haryani, Iswi, dan Serfianto, (2010), Buku Pintar Hukum Bisnis Pasar Modal. Visimedia, Jakarta Selatan.

Jamli, Ahmad, (2011), Teori Ekonomi Makro Edisi Pertama. BPFE, Yogyakarta.

Karim, Adiwarman Azwar, (2011). Ekonomi Makro Islami. PT Raja Grafindo Persada, Jakarta.

Lipsey, Richard G, dkk (1992). Pengantar Makroekonomi. Terjemahan oleh A. Jaka Wasana dan Kirbrandoko. Erlangga, Jakarta.

Mahcfoedz, Mas'ud. (1999), Akuntansi Keuangan Menengah Edisi 2. BPFE, Yogyakarta.

Mardani, (2017), Hukum Bisnis Syariah. Prenada Media, Jakarta.

Masrukhin (2019). Metodologi Penelitian Kuantitatif. Stain Kudus, Kudus.

Musthafa, (2017), Manajemen Keuangan. CV Andi Offset, Yogyakarta. 
Nugroho, Inggit dan Sukhemi. (2015), "Pengaruh Risiko Sistematis dan Likuiditas Terhadap Return Saham pada Perusahaan Manufaktur yang Terdaftar di BEI." Jurnal Akuntansi, Vol. 3, No. 2, (2015) - 3 Januari, 2019 - https://jurnalfe.ustjogja.ac.id

Oei, Istijanto, (2009). Kiat Investasi Valas, Emas, Saham: Panduan, Praktis Membiakkan Uang Lewat Valas, Emas, dan Saham yang Penuh Gejolak. Gramedia, Jakarta.

Pujawati, Putu Eka, dkk, (2015). "Pengaruh Nilai Tukar Rupiah Terhadap Return Saham dengan Profitabilitas Sebagai Variabel Intervening." Jurnal ekonomi dan Bisnis Universitas Udayana, Vol. 4, No. 4, (2015) - 3 Januari, 2019 - https://ojs.unud.ac.id

Rozak, Dede Abdul, (2013). "Pengaruh Tingkat Suku Bunga Bank Indonesia (Bi Rate) Terhadap Return Saham." Jurnal Wawasan dan Riset Akuntansi, Vol. 1, No. 1, (2013) - 4 Januari, 2019 - https://jurnal.unigal.ac.id

Samsul, Mohamad. (2006), Pasar Modal dan Manajemen Portofolio. Erlangga, Jakarta.

Siregar, Syofian. (2015), Metode Penelitian Kuantitatif Dilengkapi dengan Perbandingan Perhitungan Manual \& SPSS. Prenadamedia Group, Jakarta.

Sudarsono, Bambang dan Bambang Sudiyatno, (2016). "Faktor-Faktor yang Mempengaruhi Return Saham pada Perusahaan Property dan Real Estate yang Terdaftar pada Bursa 
Efek Indonesia." Jurnal Bisnis dan Ekonomi (JBE), Vol. 23, No. 1, (2016) - 3 Januari, 2019 - https://www.unisbank.ac.id/ojs/index.php

Sugiyono. (2014), Metode Penelitian Bisnis: Pendekatan Kuantitaif, Kualitas dan R\&D. Alfabeta, Bandung.

Suharyadi, Dan Purwanto , (2019), Statistika untuk Ekonomi dan Keuangan Modern Edisi 2. Salemba Empat, Jakarta.

Suriyani, Ni Kadek dan Gede Mertha Sudiartha, (2018). "Pengaruh Tingkat Suku Bunga, Inflasi dan Nilai Tukar Terhadap Return Saham di Bursa Efek Indonesia." Jurnal Manajemen Unud, Vol. 7, No. 6, (2018) - 2 Mei, 2019 - https://ojs.unud.ac.id

Sutedi, Adrian, (2011), Pasar Modal Syariah. Sinar Grafika, Jakarta.

Tandelilin, Eduardus, (2001). Analisis Investasi dan Manajemen Portofolio. BPFE, Yogyakarta

Tandellin, Eduardus. (2010), Portofolio dan Investasi (Teori dan Aplikasi) Edisi Pertama. Kanisius, Yogyakarta.

Umam, Khaerul, (2013). Pasar Modal Syariah dan Praktik Pasar Modal Syariah. Pustaka Setia, Bandung.

Untono, Michael, (2015). "Analisis Pengaruh Pertumbuhan Ekonomi, Inflasi, Nilai Tukar, Indek, DJIA, dan Harga Minyak Dunia Terhadap Indeks Harga Saham Gabungan." Parsimonia 2, No. 2, (2015)-4-Januari,2019 https://jurnal.machung.ac.id/index.php/parsimonia 